\title{
CORRELATION BETWEEN POLYMORPHISMS OF FOXP3 T-REGULATORY PROMOTOR GENE WITH TGF- $\beta$ IN PATIENTS WITH GRAVES' DISEASE
}

\author{
DWITYA ELVIRA* \\ Department of Internal Medicine, Allergic and Clinical Immunology Division, Dr. M. Djamil General Hospital/Medical Faculty, Andalas \\ University, Padang-Indonesia. Email: dwityaelvira@med.unand.ac.id
}

Received: 02 April 2020, Revised and Accepted: 09 May 2020

\section{ABSTRACT}

Objective: The aim of this study is to prove that there are Forkhead Box P3 (FOXP3) T-regulator promoter polymorphisms in Graves' disease and to analyze the association between FOXP3 T-regulator promoter polymorphisms with transforming growth factor (TGF)- $\beta$ levels.

Methods: This study was an observational study with cross-sectional comparative study design. Consecutive sampling was conducted in patients with Graves' disease who came to the outpatient clinic and treated in Dr. M. Djamil Hospital, Padang. Blood sampling was performed on 30 Graves' subjects and 30 control subjects based on inclusion and exclusion criteria. DNA isolation, primary construction, and polymorphism identification by polymerase chain reaction method and blood sample examination by enzyme-linked immunosorbent assay techniques method for TGF- $\beta$ examination were performed in this study.

Results: The results of this study obtained the most age of patients with Graves' disease is 30-40 years with the female gender. Graves' patient group was found to have $86.7 \%$ of single nucleotide polymorphisms (SNP) rs3761548 polymorphism, and 61.3\% had SNP rs2232365 polymorphism followed by $26.7 \%$ polymorphism of SNP rs3761547 and rs3761549, and no SNP rs2232364 polymorphism was found. In Graves' group, the mean value of TGF- $\beta$ was $1030.01 \pm 277.64 \mathrm{ng} / \mathrm{ml}$, significantly higher than the control group. Statistical analysis showed a significant relationship between polymorphism of the FOXP3 promoter gene and TGF- $\beta$ level with $\mathrm{p}<0.05$.

Conclusion: This study proves that there are polymorphisms of the FOXP3 promoter gene in Graves' patients, especially SNP rs3761548 and rs2232365. The polymorphism of the FOXP3 promoter gene has a significant association with TGF- $\beta$ levels.

Keywords: Forkhead box P3 promoter gene polymorphism, Graves' disease, Interleukin-10, Transforming growth factor- $\beta$, T-regulator.

(C) 2020 The Authors. Published by Innovare Academic Sciences Pvt Ltd. This is an open access article under the CC BY license (http://creativecommons. org/licenses/by/4. 0/) DOI: http://dx.doi.org/10.22159/ajpcr.2020.v13i7.37717

\section{INTRODUCTION}

Graves' disease is still a problem in the medical world due to the condition of hyperthyroidism which can have systemic effects on various organs of the body [1]. The incidence of Graves' disease worldwide is estimated as much as $0.4 \%$ of cases per year and is more experienced by women in the ratio of 5:1 [2,3]. In Indonesia, $0.4 \%$ of Indonesia's population aged 15 years or older has hyperthyroidism $[4,5]$.

The pathogenesis of Graves' disease involves various factors, including failure of central and peripheral tolerance of the immune system, infiltration by thyroid-directed T-cells, and activation of B cells that secrete thyroid-stimulating hormone receptor antibodies [6,7]. Other genetic factors that still attract the attention of a number of researchers are genetic factors associated with impaired central and peripheral tolerance, namely, the involvement of T-regulator cells in the pathogenesis of Graves' disease [8-10]. T-regulator cells are a subset of CD4 T cells that play an important role in autoimmune diseases, whose development and growth are regulated by the transcription gene Forkhead Box P3 (FOXP3) [11,12].

This excessive autoantibody stimulation is thought to be influenced by the FOXP3 gene which is the main transcription factor that regulates the development and function of T-regulator cells $[8,13]$. The FOXP3 gene, also known as scurfin, is a protein involved in the immune response. The FOX protein from FOXP3 is a forkhead/winged-helix family that plays a role in the transcription process of T-regulator cells $[14,15]$.

In carrying out its regulator function, T-reg cells secrete cytokines transforming growth factor (TGF)- $\beta$ which function to suppress the excessive activity of T-helper cells. TGF- $\beta$ is a pleiotropic cytokine that plays a role in proliferation, differentiation, migration, and intracellular survival. TGF- $\beta$ cytokines produced by T-regulator cells can inhibit B cell proliferation through TGF- $\beta$ stimulation in interleukin (IL)-17 [16-18]. In Graves' disease, the effects of these cytokines on Graves' disease are still not known with certainty [19].

Based on the background description above, this study was conducted to prove the relationship between T-regulator gene polymorphisms and Graves' disease and their relationship with TGF- $\beta$ cytokines produced by T-regulator cells.

\section{METHODS}

This was a cross-sectional comparative study conducted in the internal medicine department in Dr. M. Djamil Hospital and Biomedical Laboratory Andalas University, Padang, West Sumatera, Indonesia. This study involved 30 patients with Graves' disease and 30 control subjects who have signed the informed consent. Allergic, Hashimoto thyroiditis, other autoimmune diseases, and corticosteroid consuming patients were excluded from the study. All blood samples have taken from these study participants for laboratory tests. All patients have provided a signed consent. This research has received an ethical approval from the Ethics Committee of the Medical Faculty of Andalas University.

\section{Examination methods}

DNA isolation, primary construction, and polymorphism identification by polymerase chain reaction method and blood sample examination by enzyme-linked immunosorbent assay techniques method for TGF- $\beta$ examination were performed in this study. 
Statistical analysis

Univariate analysis was carried out to see the data distribution of each variable and then presented in the form of a frequency table. The data consisted of the characteristics of the FOXP3 gene polymorphism and serum TGF- $\beta$ cytokine levels. Bivariate analysis was then performed to determine the relationship between the two groups by performing a Chi-square test.

\section{RESULTS}

There are 30 patients and 30 control subjects in this study. There are more females than men (76.7\% vs. $23.3 \%)$. This difference was not statistically significant ( $p>0.05)$. The mean age of patients with Graves was slightly higher than the average age of healthy controls $(40.23 \pm 9.98$ vs. 39.6 \pm 9.76 ). This difference was not statistically significant ( $p>0.05)$. The 31-40 years age group is the most common age group in both Graves and control patients. The youngest to experience Graves' disease is 21 years and the oldest is 59 years. Baseline characteristics are shown in Table 1.

From 30 Graves' disease subjects, we found 4 of 5 polymorphisms of single nucleotide polymorphisms (SNP) FOXP3 promotor gene, which are - 924A/G (rs2232365), - 3499A/G (rs3761547), - 3279C/A (rs3761548), and - 2383C/T (rs3761549). Polymorphisms of SNP rs3761548 dan rs2232365 are that the most SNP found in this study.

In Table 2, it can be seen that the mean TGF- $\beta$ level in the Graves' disease patient group is higher than the control group that is $1030.01 \pm 277.64$ $\mathrm{ng} / \mathrm{ml}$ compared to $889.72 \pm 37.86 \mathrm{ng} / \mathrm{ml}$. Statistically, significant differences were obtained between the two groups $(\mathrm{p}<0.05)$.

In Table 3, it can be seen that the mean TGF- $\beta$ level in Graves' disease patients who experienced SNP polymorphism rs2232365 was higher than Graves' disease patients who did not experience polymorphism $(1082.61 \pm 290.22 \mathrm{ng} / \mathrm{ml}$ vs. $939.16 \pm 239.9 \mathrm{ng} / \mathrm{ml})$. Statistical tests showed an association between FOXP3 SNP gene polymorphism rs2232365 with TGF- $\beta$ cytokine levels in patients with Graves' disease with $\mathrm{p}<0.05$.

Table 1: Baseline characteristics

\begin{tabular}{|c|c|c|c|c|c|}
\hline \multirow[t]{2}{*}{ Variable } & \multicolumn{2}{|c|}{ Graves' disease } & \multicolumn{2}{|l|}{ Control } & \multirow[t]{2}{*}{ p } \\
\hline & n (30) & $\%$ & n (30) & $\%$ & \\
\hline \multicolumn{6}{|l|}{ Sex } \\
\hline Male & 7 & 23.3 & 7 & 23.3 & 1.00 \\
\hline Female & 23 & 76.7 & 23 & 76.7 & \\
\hline Age, mean \pm SD & $40.23 \pm 9.98$ & & $39.6 \pm 9.76$ & & 0.805 \\
\hline $21-30$ yo & 5 & 16.7 & 7 & 23.3 & \\
\hline $31-40$ уо & 11 & 36.7 & 9 & 30 & \\
\hline $41-50$ уо & 8 & 26.7 & 8 & 26.7 & \\
\hline 51-60 уо & 6 & 20 & 6 & 20 & \\
\hline
\end{tabular}

Table 2: TGF- $\beta$ levels in Graves' disease and control group

\begin{tabular}{lllll}
\hline Group & N & Mean $(\mathbf{n g} / \mathbf{m l})$ & SD & P \\
\hline Graves' disease & 30 & 1030.01 & 277.64 & $\mathrm{p}=0.000$ \\
Control & 30 & 889.72 & 37.86 & \\
\hline
\end{tabular}

TGF: Transforming growth factor

Table 3: Association between polymorphisms of FOXP3 promotor gene with TGF- $\beta$ levels in Graves' disease patients

\begin{tabular}{lllll}
\hline \multirow{2}{*}{$\begin{array}{l}\text { Polymorphisms } \\
\text { of FOXP3 }\end{array}$} & Total & TGF- $\boldsymbol{\beta}$ & \multirow{2}{*}{$\mathbf{p}$} \\
\cline { 3 - 4 } & & Mean & SD & \\
\hline rs2232365 & Present $(n=19)$ & 1082.61 & 290.22 & \multirow{2}{*}{0.023} \\
& Absent $(n=11)$ & 939.16 & 239.9 & \\
\hline TGF: Transforming & Prowth factor F0XP3: & &
\end{tabular}

TGF: Transforming growth factor, FOXP3: Forkhead Box P3

\section{DISCUSSION}

Characteristics of gender and age did not differ significantly between Graves' disease patient group and control group. In this study, the age range between 31 and 40 years group and the female group is the most age and sex group who experience Graves' disease. This is consistent with the American Thyroid Association data which explain that although Graves' disease can occur in all ages, it is more common in women than men in the 7-8:1 ratio. Like most other autoimmune diseases, female sex is the group that most often experiences autoimmune disease. It is thought that the role of the hormone estrogen in stimulating antibody and autoantibody production through B cells. Estrogen also increases IL-4, IL-10, and TGF- $\beta$ levels and expression of CD80 and FOXP3, which further increases cytotoxic T-lymphocyte-associated Protein-4 (CTLA-4) activity and T-reg cell population [20-22].

In this study, no difference was found between SNP FOXP3 gene promoter polymorphisms in Graves' disease patients with controls ( $p>0.05$ ) for each SNP. This is consistent with the study of Owen et al. in the United Kingdom population which shows that there is no correlation between the polymorphism of the FOXP3 gene and healthy control, while different results are shown by Lei and Yang. 2015 research examining the Graves population in the Han Chinese population which shows that there is a difference between SNP polymorphism rs3761548 with healthy controls $[12,23]$.

This is caused by the many factors that influence the incidence of Graves' disease, both other genetic and environmental factors. A study by Eliana et al. showed that there is a polymorphism of the base CTLA4 gene 49 codons 17 exons 1 in Graves' disease patients by comparing between relapse and non-relapse Graves' disease patients $(\mathrm{p}=0.016)$. CTLA4 is one of the markers on the surface of T-regulator cells which also play a role in immune homeostasis along with the FOXP3 gene in intracellular T-regulators. Recent research also showed that environmental factors can also interact with certain genes that cause susceptibility to Graves' disease through epigenetic modulation, such as histone modifications. The study of Yan et al. found that histone levels of $\mathrm{H} 4$ acetylation decreased in patients with Graves' disease, while levels of histone deacetylase (HDAC)-1 and HDAC 2 were very high which showed that there was a change or modification of histones in patients with Graves' disease. However, studies on the role of histone modification in Graves' disease itself have not been done much, especially regarding the histone-modifying gene Sirtuin 1 which is thought to influence the occurrence of histone modification in patients with Graves' disease [24,25].

The results of this study prove the presence of FOXP3 gene promoter polymorphisms in Graves' disease. The mean TGF- $\beta$ level in Graves' disease patients who experienced SNP polymorphism rs2232365 was higher than those who did not. Statistically, there was a significant relationship between FOXP3 gene polymorphisms and the mean TGF- $\beta$ levels in patients with Graves' disease with $\mathrm{p}<0.05$.

The Hassannia et al. study showed a significant relationship between the polymorphism of the FOXP3 rs3761548 gene and peripheral TGF- $\beta$ cytokine expression [26-28]. Elvira's research showed that there is an increase in FOXP3 T-regulator levels in patients with Graves. This increase in T-regulator is followed by an increase in the secretion of cytokines produced by T-regulator cells which include TGF- $\beta$ and IL-10. This study also showed an increase in TGF- $\beta$ levels in Graves' disease compared with healthy controls [27-32].

\section{CONCLUSION}

This study proves that there are polymorphisms of the FOXP3 promoter gene in Graves' patients, especially SNP rs3761548 and rs2232365. The mean TGF- $\beta$ levels were higher in the Graves' disease group compared to control. The polymorphism of the FOXP3 promoter gene has a significant association with TGF- $\beta$ levels. 


\section{ACKNOWLEDGMENT}

The author would like to thank Andalas University and Biomedical Laboratorium - Medical Faculty for providing the facilities to conduct the research.

\section{AUTHOR'S CONTRIBUTIONS}

Dwitya Elvira concepted the research, provided the methods, collected, and analyzed the data, and authored the manuscript.

\section{CONFLICTS OF INTEREST}

The author declare that they have no conflicts of interest in publishing this research article.

\section{AUTHOR'S FUNDING}

This research was funded by Andalas University (UNAND) through LPPM. This research included in Klaster Riset Doktor UNAND 2018.

\section{REFERENCES}

1. Idrose AM. Acute and emergency care for thyrotoxicosis and thyroid storm. Acute Med Surg 2015;2:147-57.

2. Brent GA. Graves' disease. N Engl J Med 2008;358:2594-605.

3. Girgis C, Champion B, Wall J. Current concepts in graves' disease. Ther Adv Endocrinol Metab 2011;2:135-44.

4. Decroli E, Elvira D, Aprilia A. The effect of thionamide to TRH, TSH, IL-4, T-reg, and anti-TPO in graves' disease. Indones J Pharm 2019;30:122-7.

5. Decroli E, Manaf A, Syahbuddin S. Immunologic and hormonal effects of propylthiouracil treatment using maintenance dose in graves' disease. Acta Med Indones 2014:46:314-9.

6. Davies TF. Infection and autoimmune thyroid disease. J Clin Endocrinol Metab 2008;93:674-6.

7. Lombardi A, Menconi F, Greenberg D, Concepcion E, Leo M, Rocchi R, et al. Dissecting the genetic susceptibility to graves' disease in a cohort of patients of Italian origin. Front Endocrinol 2016;7:1-7.

8. Ban Y, Tozaki T, Tobe T, Ban Y, Jacobson E, Concepcion E, et al. The regulatory $\mathrm{T}$ cell gene FOXP3 and genetic susceptibility to thyroid autoimmunity: An association analysis in caucasian and Japanese cohorts. J Autoimmun 2007;28:201-7.

9. Ngalamika O, Zhang Y, Yin H, Zhao M, Gershwin M, Lu Q. Epigenetics, autoimmunity and hematologic malignancies: A comprehensive review. J Autoimmun 2012;39:451-65.

10. Li H, Chen Q. Genetic susceptibility to graves' disease. Front Biosci 2013;18:1080-7.

11. Bossowski A, Borysewicz-Sanczyk H, Wawrusiewicz-Kurylonek N, Zasim A, Szalecki M, Wikiera B, et al. Analysis of chosen polymorphisms in FoxP3 gene in children and adolescents with autoimmune thyroid diseases. Autoimmunity 2014;47:395-400.

12. Lei ZW, Yang ZL. Association between FOXP3, FOXE1 gene polymorphisms and risk of differentiated thyroid cancer in Chinese Han population. Mol Biol 2015;4:1-5.

13. Wang YM, Ghali J, Zhang GY, Hu M, Wang Y, Sawyer A. Development and function of FOXP3 (+) regulatory T cells. Nephrology 2016;21:81-5.

14. Peterson R. Regulatory T-cells: Diverse phenotypes integral to immune homeostasis and suppression. Toxicol Pathol 2012;40:186-204.

15. Oda J, Hirata B, Guembarovski R, Watanabe M. Genetic polymorphism in FOXP3 gene: Imbalance in regulatory T-cell role and development of human diseases. J Genet 2013;92:163-71.

16. Chen W, Konkel JE. TGF-beta and "adaptive" Foxp3(+) regulatory T cells. J Mol Cell Biol 2010;2:30-6.

17. Chen X, Oppenheim JJ. Contrasting effects of TNF and anti-TNF on the activation of effector $\mathrm{T}$ cells and regulatory $\mathrm{T}$ cells in autoimmunity. FEBS Lett 2011;585:3611-8.

18. Tran D. TGF-beta: The sword, the wand, and the shield of FOXP3(+) regulatory T cells. J Mol Cell Biol 2012;4:29-37.

19. Kristensen B, Hegedus L, Lundy S, Brimnes M, Smith T, Nielsen C. Characterization of regulatory B cells in graves' disease and hashimoto's thyroiditis. PLoS One 2015;10:e127949.

20. Fairweather D, Frisancho-Kiss S, Rose NR. Sex differences in autoimmune disease from a pathological perspective. Am J Pathol 2008;173:600-10.

21. Ngo ST, Steyn FJ, McCombe PA. Gender differences in autoimmune disease. Front Neuroendocrinol 2014;35:347-69.

22. Khan D, Ahmed SA. The immune system is natural target for estrogen action: Opposing effects of estrogen in two prototypical autoimmune diseases. Front Immunol 2016;6:1-8

23. Owen CJ, Eden JA, Jennings CE, Wilson V, Cheetham TD, Pearce S. Genetic association studies of the FOXP3 gene in graves' disease and autoimmune addison's disease in the United Kingdom population. J Mol Endocrinol 2006;37:97-104.

24. Wang B, Shao X, Song R, Xu D, Zhang J. The emerging role of epigenetics in autoimmune thyroid diseases. Front Immunol 2017;8:1-13.

25. Yan N, Zhou JZ, Zhang JA, Cai T, Wang Y, et al. Histone pre-acetylation and increased histone deacetylases in peripheral blood mononuclear cells from patients with graves' disease. Mol Cell Endocrinol 2015;414:143-7.

26. Hassannia H, Abediankenari S, Ghaffari J. FOXP3 and TGF- $\beta$ gene polymorphisms in allergic rhinitis. Iran J Immunol 2011;8:218-25.

27. Elvira D, Darwin E. Role of pro-inflammatory and regulatory cytokines in pathogenesis of graves' disease in association with autoantibody thyroid and regulatory FoxP3 T-cells. Int J Med Health Sci 2017;11:69-72.

28. Elvira D. The role of T-regulatory expression in autoimmune thyroid disease and its association with thyroid antibody. J Autoimmun Disord 2016;2:19.

29. Sarkar D, Chakraborty A, Bhattacharya C, Singh LH, Chandra AK. Exploration of goitrogenic/antithyroidal potentiality of bamboo-shoots in relation to thiourea. Int J Pharm Pharm Sci 2017;9:7-12.

30. Saptarini NM, Wibowo MS, Gusnidar T. Correlation study of age, disease duration, and erythrocyte sedimentation rate among the Indonesian rheumatoid arthritis patients. Int $\mathrm{J}$ Pharm Pharm Sci 2015;7:274-7

31. Decroli E, Manaf A, Syahbuddin S, Waspadji S, Dillasamola D. The role of survivin and raf-1 kinase against enhancement of pancreatic beta-cell apoptosis in patients with Type 2 diabetes mellitus. Asian J Pharm Clin Res 2018;11:344-7.

32. Santoso DI, Yunita S, Paramita N, Andraini T, Kartinah NT, Bayani GF, et al. Effect of Hibiscus sabdariffa Linn on IL-6 and TNF- $\alpha$ levels in overtrained rat heart. Int J App Pharm 2019;11:42-5. 